\title{
In vitro Antimicrobial Potency of Lemon Fruit (Citrus limon) Extract on Salmonella typhi
}

\author{
Farhan Haidar Fazlur Rahman ${ }^{1}$, Lindawati Alimsardjono ${ }^{2^{\star}}$, Sunarni Zakaria ${ }^{3}$
}

\begin{abstract}
${ }^{1}$ Faculty of Medicine, Universitas Airlangga/Dr. Soetomo General Hospital, Surabaya, Indonesia.
${ }^{2}$ Department of Clinical Microbiology, Faculty of Medicine, Universitas Airlangga/Dr. Soetomo General Hospital, Surabaya, Indonesia.

${ }^{3}$ Department of Pharmacology, Faculty of Medicine, Universitas Airlangga/Dr. Soetomo General Hospital, Surabaya, Indonesia.
\end{abstract}

A B S T R A C T

Introduction: This study aimed to evaluate minimum inhibitory concentration (MIC) and minimum bactericidal concentration (MBC) of lemon fruit (Citrus limon) extract in inhibiting Salmonella typhi growth in vitro.

Methods: This research was categorized as a laboratory experimental study. Lemon fruit (Citrus limon) extract was prepared with concentration as follows: 100.000 ppm, 50.000 ppm, 25.000 ppm, 12.500 ppm, 6.250 ppm, 3.125 ppm, 1.562 ppm, 781 ppm, and $390 \mathrm{ppm}$. Dilution tests with Mueller-Hinton broth medium were performed to determine the MIC. After 24 hours of incubation, isolated Salmonella typhi inside the tube was inoculated back in MacConkey agar plate medium to determine the MBC. Replications were conducted 3 times according to Federer's formula.

Results: MIC of lemon fruit (Citrus limon) extract to Salmonella typhi was determined at $3.125 \mathrm{ppm}$. Meanwhile, MBC was determined at $6.250 \mathrm{ppm}$.

Conclusion: This study showed the potential antimicrobial effect of lemon fruit (Citrus limon) extract against Salmonella typhi in-vitro. Further studies are still needed to determine its efficacy and safety in vivo and also its full antibacterial spectrum.

() 2020 JUXTA: Jurnal IImiah Mahasiswa Kedokteran Universitas Airlangga.

Available at https://e-journal.unair.ac.id/juxta

* Correspondence: lindawatia@gmail.com

JUXTA: Jurnal IImiah Mahasiswa Kedokteran Universitas Airlangga

p-ISSN: 1907-3623; e-ISSN: 2684-9453

DOI: $10.20473 /$ juxta.V11122020.69-73

Open access under Creative Commons Attribution-ShareAlike 4.0 International License (CC-BY-SA)
ARTICLE INFO

Article history:

Received 5 June 2020

Received in revised form 2 July 2020

Accepted 3 July 2020

\section{Keywords:}

Salmonella typhi,

Citrus limon,

Antimicrobial,

MIC,

MBC. 


\section{Introduction}

Salmonella typhi is a bacteria that belongs to Enterobacteriaceae family, which is a large group of gramnegative rod bacteria. ${ }^{1}$ Salmonella typhi is transmitted to humans through the faecal-oral route, human to human contact, or through contaminated food and beverages. ${ }^{2}$ Infections caused by Salmonella typhi conditions often cause serious and life-threatening illness. Salmonella typhi causes at least 21 million infections and approximately 200.000 deaths annually. ${ }^{3}$

Chloramphenicol has been the drug of choice for Salmonella infections due to either typhoid or non-typhoid since 1948. Chloramphenicol has reduced deaths from typhoid from $20 \%$ to less than $1 \%$ and reduced the duration of fever 2-4 weeks to 4-5 days. ${ }^{4}$ These are some reasons why chloramphenicol has been the primary choice for Salmonella infections since long ago. ${ }^{4}$

Chloramphenicol has excellent cellular penetration and it makes chloramphenicol can be widely distributed in the body ${ }^{4}$. However, it turns out that chloramphenicol also has side effects that could be dangerous. The use of chloramphenicol can cause effects such as bone marrow suppression and the most feared effect is aplastic anemia ${ }^{4}$. Moreover, lately it is known that Salmonella typhi has fluoroquinolone-class-of-antibiotic resistance, and there is also a significant increment in resistance of Salmonella typhi towards nalidixic acid. ${ }^{5}$ These things lead to the need for an alternative antibiotic treatment for diseases caused by Salmonella typhi infection.

Lemon fruit (Citrus limon) belongs to Rutaceae family. Lemon fruit extract is believed to have potential in the field of medicine. Some studies show that lemon fruit extract has antioxidant activity, antifungal, and antibacterial effect. ${ }^{6}$ The content of chemical compounds from a lemon that has activity as mentioned above include flavonoids and linalool.

In other researches about the sensitivity test of Lime (Citrus aurantifolia) extract to Salmonella typhi, it was proven that the lime juice on all treatments inhibit the growth of Salmonella typhi ${ }^{6}$. Meanwhile, no other study ever found the antimicrobial potency of lemon fruit extract.

This study aimed to find the potency of antimicrobial effect of lemon fruit (Citrus limon) extract towards Salmonella typhi. For knowledge and science, this research is expected to provide scientific information about the effectiveness of lemon fruit (Citrus limon) extract against Salmonella typhi bacteria. For professional application, this research is expected to answer whether lemon fruit extract can be used as an alternative treatment for Salmonella typhi bacteria or not.

\section{Methods}

This study was categorized as a laboratory experimental study, designed to measure the antibacterial activity of lemon fruit extract in inhibiting the growth of Salmonella typhi bacteria using dilution method in vitro to know the MIC and MBC result. Sample of Salmonella typhi bacteria was obtained from Microbiology Laboratory,
Faculty of Medicine, Universitas Airlangga, Surabaya. Meanwhile, the sample of lemon fruit extract was made at Pharmacognosy Laboratory, Faculty of Pharmacy, Universitas Airlangga, Surabaya.

First of all, lemon fruit extract was needed to be prepared. It started with fresh lemon fruit that had been peeled from its skin as much as 455 grams. Lemons that had been prepared then were squeezed through a filter into a container. Freshly squeezed lemon juice then soaked with $96 \%$ ethanol for 24 hours. After the soaking process was completed, then the filtering process was done. The result of the filtration then soaked and filtered again in a similar manner. After 3 rounds of soaking and filtration during 3×24 hours, obtained liquid extract was concentrated by using a rotary evaporator. The result was then obtained lemon fruit extract concentrated and ready to be used as experimental materials.

As many as 11 tubes filled with Mueller-Hinton broth medium were prepared. Each media was labelled M1 through M9, as well as two control tubes, the $\mathrm{K}+$, and $\mathrm{K}$ Then, setting up the M1 as initial dilution media. Media M1 was filled with $1 \mathrm{~mL}$ of the lemon fruit (Citrus limon) extract with the highest concentration of $100.000 \mathrm{ppm}$. Those steps were continued respectively until media M9 was filled with dilution predetermined concentration and ensured that each media volume was equal to any other.

$\mathrm{K}$ - tube as the negative control, the media was filled with extracts of lemon (Citrus limon) concentration of 100.000 ppm. K+ tube as the positive control was filled only with a suspension of Salmonella typhi bacteria. All media were incubated for 24 hours at a temperature of $37^{\circ} \mathrm{C}$. Then MIC value was determined. After that, the liquid dilution test in Mueller-Hinton medium broth was streaked to MacConkey agar plate to determine the value of MBC. Streaking results were then incubated for 24 hours at a temperature of $37^{\circ} \mathrm{C}$.

\section{Results}

MIC was visually being observed by comparing each tube with the negative control tubes. MIC was determined from the least lemon fruit extract concentration, it was needed to make the tubes clear. The turbidity from each tube indicated that there was a Salmonella typhi growth in the tubes. In this research, it is shown that M1, M2, M3, M4, $\mathrm{M} 5$, and $\mathrm{M} 6$ have the same clarity as negative control tubes (K-). Meanwhile, M7, M8, and M9 have turbidity which is the same as positive control tubes $(\mathrm{K}+)$. Therefore, the MIC for this research was determined at tube M6, which is valued at $3.125 \mathrm{ppm}$.

These are the results for dilution test to determine the MIC of lemon fruit extract to Salmonella typhi. 


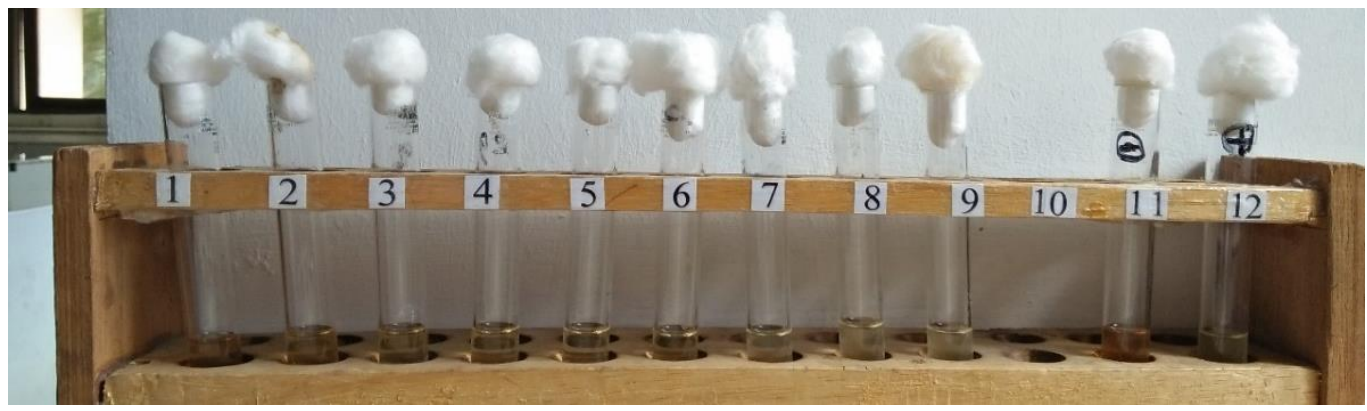

Figure 1. Dilution test in Mueller-Hinton broth to determine MIC.

Table 1. Results of the dilution test.

\begin{tabular}{|c|c|c|c|c|c|c|c|c|c|c|c|}
\hline \multirow[t]{2}{*}{ Replication } & \multicolumn{9}{|c|}{ Lemon Fruit Extract Concentration } & \multicolumn{2}{|c|}{ Control } \\
\hline & $\begin{array}{l}100.000 \\
\text { ppm } \\
\text { (M1) }\end{array}$ & $\begin{array}{c}50.000 \\
\text { ppm } \\
\text { (M2) }\end{array}$ & $\begin{array}{c}25.000 \\
\text { ppm } \\
\text { (M3) }\end{array}$ & $\begin{array}{c}12.500 \\
\text { ppm } \\
\text { (M4) }\end{array}$ & $\begin{array}{l}6.250 \\
\text { ppm } \\
\text { (M5) }\end{array}$ & $\begin{array}{l}3.125 \\
\text { ppm } \\
\text { (M6) }\end{array}$ & $\begin{array}{l}1.562 \\
\text { ppm } \\
\text { (M7) }\end{array}$ & $\begin{array}{l}781 \\
\text { ppm } \\
\text { (M8) }\end{array}$ & $\begin{array}{l}390 \\
\text { ppm } \\
\text { (M9) }\end{array}$ & + & - \\
\hline 1 & $\mathrm{x}$ & $x$ & $x$ & $x$ & $\mathrm{x}$ & $x$ & 0 & 0 & 0 & 0 & $x$ \\
\hline 2 & $x$ & $x$ & $x$ & $x$ & $x$ & $x$ & 0 & 0 & 0 & 0 & $x$ \\
\hline 3 & $x$ & $x$ & $x$ & $x$ & $x$ & $x$ & 0 & 0 & 0 & 0 & $x$ \\
\hline
\end{tabular}

Source: Research data, processed

Meanwhile, determination for the MBC of lemon fruit extract was performed by inoculating suspension in each tube into MacConkey agar plate and see if there are any growth from Salmonella typhi after incubated for 24 hours in $37^{\circ} \mathrm{C}$ temperature.

As we can see in figure $2, M B C$ was visually observed from the culture to see if there was any growth of bacteria.

\section{Information}

$x \quad$ : Clear, bacteria inhibited

o : : Turbid, bacteria non-inhibited
From the experiment, it is found that M6, M7, M8, and M9 plates have Salmonella typhi growth in it, meanwhile in M1, M2, M3, M4, and M5 plates there are no signs of any bacteria growth. From the table below we can conclude that from each replication we find same data. The MBC was determined at $6.250 \mathrm{ppm}$ in the M5 plate.

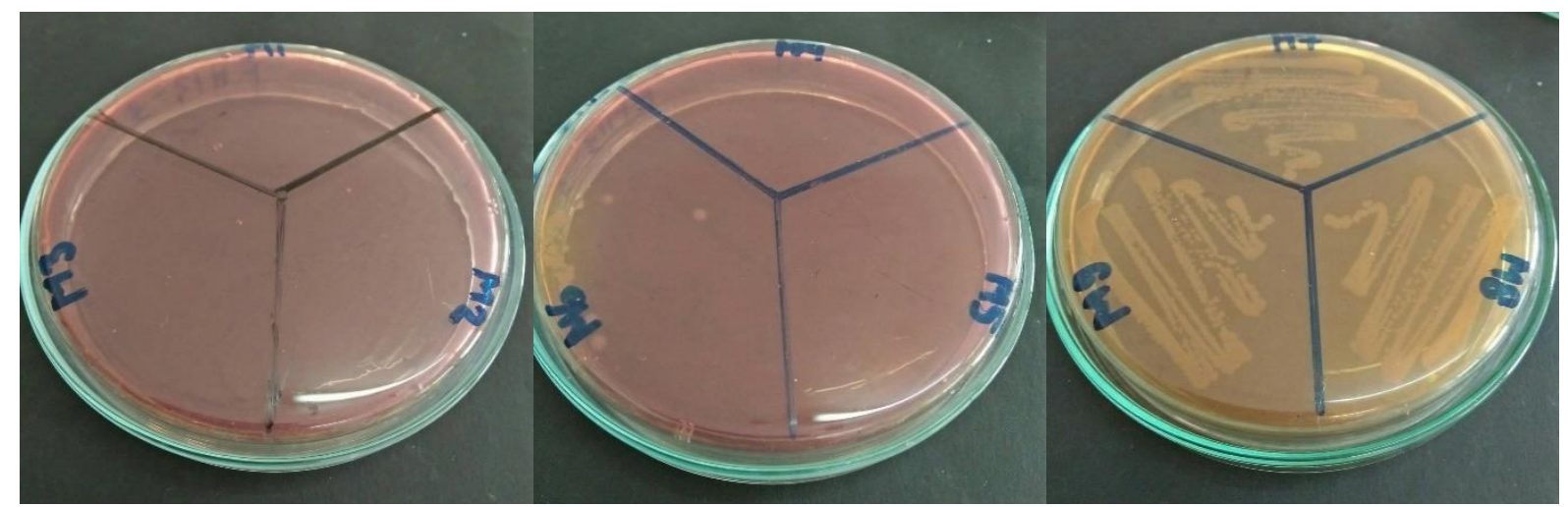

Figure 2. Streaking the dilution results on blood agar plates in replication 1 to find the MBC.

Table 2. Results of the streaking test.

\begin{tabular}{|c|c|c|c|c|c|c|c|c|c|c|c|}
\hline \multirow[t]{2}{*}{ Replication } & \multicolumn{9}{|c|}{ Lemon Fruit Extract Concentration } & \multicolumn{2}{|c|}{ Control } \\
\hline & $\begin{array}{c}100.000 \\
\text { ppm } \\
(M 1)\end{array}$ & $\begin{array}{c}50.000 \\
\text { ppm } \\
(\mathrm{M} 2)\end{array}$ & $\begin{array}{l}25.000 \\
\text { ppm } \\
(\mathrm{M} 3)\end{array}$ & $\begin{array}{c}12.500 \\
\text { ppm } \\
\text { (M4) }\end{array}$ & $\begin{array}{l}6.250 \\
\text { ppm } \\
\text { (M5) }\end{array}$ & $\begin{array}{l}3.125 \\
\text { ppm } \\
(\mathrm{M} 6)\end{array}$ & $\begin{array}{l}1.562 \\
\text { ppm } \\
(\mathrm{M} 7)\end{array}$ & $\begin{array}{l}781 \\
\text { ppm } \\
\text { (M8) }\end{array}$ & $\begin{array}{l}390 \\
\text { ppm } \\
\text { (M9) }\end{array}$ & + & - \\
\hline 1 & - & - & - & - & - & + & + & + & + & + & - \\
\hline 2 & - & - & - & - & - & + & + & + & + & + & - \\
\hline 3 & - & - & - & - & - & + & + & + & + & + & - \\
\hline Source: & dat & ces & & & $\begin{array}{l}\text { Infor } \\
- \\
+\end{array}$ & $:$ The & $\begin{array}{l}\text { no } \\
\text { a gr }\end{array}$ & $\begin{array}{l}\text { th } \\
\text { h of }\end{array}$ & $\begin{array}{l}\text { Salm } \\
\text { almo }\end{array}$ & & \\
\hline
\end{tabular}




\section{Discussion}

The biological activity associated with the antibacterial properties of lemon is probably related to the total polyphenols and flavonoids contained in a lemon. In several previous studies, total polyphenols and flavonoids contained in a substance were shown to affect the antimicrobial activity. ${ }^{7}$

Flavonoids are phenolic substances which have the effect of therapeutic potential against microorganisms. The basic structure of flavonoids consists of 15 carbon atoms, and 3 rings consist of 2 benzene rings connected by a three-carbon chain. Some types of flavonoids are usually found in plants which are considered as a good deterrent against free radicals and oxidative stress in vivo. ${ }^{8}$ Flavonoids can form complexes with extracellular protein, fat-soluble protein, and the bacterial cell wall. It also has lipophilic nature that can damage the membranes of microbes. ${ }^{9}$ Flavonoids are also a highly effective disinfectant and inhibit bacterial growth because flavonoids are polar, making it easier to penetrate the peptidoglycan layer.

Upon successful login, flavonoids work immediately to destroy bacteria by initializing the denaturation of proteins which can cause bacterial cell metabolic activity stops. This is because all of the metabolic activity of the bacterial cell of Sallmonella typhi are catalyzed by enzymes formed by proteins. Cessation of metabolic activity will result in bacterial cell death. ${ }^{10}$ The absence of this protein as an enzyme ultimately caused the death of Salmonella typhi.

Meanwhile, the substance of linalool is known to have a specific employment targets lipopolysaccharide. So it can be said that linalool specifically works on lipopolysaccharide in the bacterial membrane. Linalool causes the membrane potential depolarization takes place more rapidly to inhibit the synthesis of proteins, DNA, and RNA. This will then lead to bacterial cell death. ${ }^{11}$ Linalool which is a derivative of phenol also has a target site at the cell membrane. Linalool killing power is due to phenol precipitate active protein and cell membrane damage by lowering the surface tension ${ }^{6}$.

During this time chloramphenicol has become one of the major therapeutic agents in the treatment of infections due to Salmonella typhi. Chloramphenicol is an inhibitor of microbial protein synthesis and has a reversible bonding compound on bacterial ribosomal subunit and inhibits the peptidyl transferase stage in protein synthesis. Chloramphenicol is a broad-spectrum antibiotic bacteriostatic and is active against gram-negative and gram-positive, both aerobic and anaerobic. ${ }^{4}$

By those working mechanisms of chloramphenicol, it can be said that the lemon fruit extract and chloramphenicol have a similar mechanism of action by blocking the action and protein synthesis in Salmonella typhi bacteria. It could also mean that the active compounds in the lemon fruit extract have antibacterial mechanism that has not been recognized previously by Salmonella typhi, so that these bacteria remain sensitive to lemon extracts. Although it has been widely used as primary therapy for infectious diseases caused by Salmonella typhi, chloramphenicol also has side effects that could be dangerous. The use of chloramphenicol can cause effects such as bone marrow suppression and the most feared is aplastic anemia. ${ }^{4}$

Based on this study, it can be said that the lemon fruit extract may be an alternative in the medical world as a treatment for infections caused by Salmonella typhi. Of course, with further research both clinically and nonclinically. Further studies are needed to determine the effect of lemon fruit extract against Salmonella typhi in vivo in to make sure whether it can be accepted as an alternative therapy in medicine. Further research is also necessary to know the side effects of lemon fruit (Citrus limon) extract in vivo. Lastly, similar research should also be done but with a wider variety of bacteria known to be the antibacterial spectrum of the lemon fruit (Citrus limon) extract.

\section{Conclusion}

Lemon fruit (Citrus limon) extract is effective in inhibiting the growth of Salmonella typhi, with MIC of 3.125 ppm and MBC of 6.250 ppm.

\section{CONFLICT OF INTEREST}

The author stated there is no conflict of interest in this study.

\section{REFERENCES}

1. Brooks GF, Carroll KC, Butel JS, Morse SA and Mietzner TA. Jawetz, Melnick, \& Adelberg's Medical Microbiology. 25th ed. New York: McGraw-Hill Medical, 2010.

2. Gonzalez-Lopez JJ, Piedra-Carrasco N, Salvador F, et al. ESBL-Producing Salmonella Enterica Serovar Typhi in Traveler Returning From Guatemala to Spain. Emerging Infectious Diseases. 2014; 20: 1918-20.

3. Gonzalez-Escobedo G, Marshall JM and Gunn JS. Chronic and Acute Infection of the Gall Bladder by Salmonella Typhi: Understanding the Carrier State. Nature Reviews Microbiology. 2011; 9: 9-14.

4. Katzung BG, Masters SB and Trevor AJ. Farmakologi Dasar dan Klinik. 12th ed. Jakarta: Penerbit Buku Kedokteran EGC, 2012.

5. Holt KE, Dolecek C, Chau TT, et al. Temporal Fluctuation of Multidrug Resistant Salmonella Typhi Haplotypes in the Mekong River Delta Region of Vietnam. Plos Neglected Tropical Diseases. 2011; 5: E929.

6. Brillian B. Uji Daya Hambat Air Perasan Jeruk Nipis (Citrus Aurantifolia) terhadap Pertumbuhan Bakteri Salmonella Typhi Secara In Vitro. Fakultas Kedokteran, 2014.

7. Lee $\mathrm{JH}$, Cho S, Paik HD, et al. Investigation on Antibacterial and Antioxidant Activities, Phenolic and Flavonoid Contents of Some Thai Edible Plants as an Alternative for Antibiotics. Asian-Australasian Journal of Animal Sciences. 2014; 27: 1461-8.

8. Alam MA, Subhan N, Rahman MM, Uddin SJ, Reza HM and Sarker SD. Effect of Citrus Flavonoids, Naringin and Naringenin, On Metabolic Syndrome and Their Mechanisms of Action. Advances in Nutrition (Bethesda, MD). 2014; 5: 404-17. 
9. Shad AA, Ahmad S, Ullah R, et al. Phytochemical and Biological Activities of Four Wild Medicinal Plants. The Scientific World Journal. 2014; $2014: 7$.

10. Suerni E. Uji Daya Hambat Ekstrak Buah Nanas (Ananas comosus L.Merr.), Salak (Salacca edulis Reinw.) dan Mangga Kweni (Mangifera odorata Griff.) terhadap Daya Hambat Staphylococcus aureus. Biocelebes, 2015.
11. Swandika B, Wahyunitisari M and Purwaningsih S. Efek Antimikroba Ekstrak Daun Mentha Piperita terhadap Methicillin-resistant Staphylococcus Aureus. Indonesian Journal of Tropical Medicine and Hygiene. 2012; 1. 